Nadine Böhm-Schnitker, Marcus Hartner (eds.)

Comparative Practices

Culture \& Theory | Volume 258 
Nadine Böhm-Schnitker is a senior lecturer in English Studies: Literature and Culture at Friedrich-Alexander-Universität Erlangen-Nürnberg and serves as an interim professor of English Literature and Literary Theory at the University of Konstanz. She is a former associate member of the Collaborative Research Centre 1288 »Practices of Comparing « funded by the German Research Foundation (DFG) and particularly interested in the power imbalances entailed in practices of comparing. Her further interests include contemporary literature and culture (e.g. neo-Victorian studies, BrexLit), the literary and cultural impact on perception, as well as cultural responses to ecological concerns such as climate change.

Marcus Hartner is a senior lecturer in English Studies at Bielefeld University. He is an associate member and former principal investigator of the Collaborative Research Centre 1288 »Practices of Comparing « funded by the German Research Foundation (DFG). His main fields of research encompass the study of narrative and the intersection of race, gender, and class in early modern literature and culture. Among his further research interests are the study of migration literature, maritime humanities, and Anglo-Muslim relations in the sixteenth and seventeenth centuries. 
Nadine Böhm-Schnitker, Marcus Hartner (eds.)

\section{Comparative Practices}

Literature, Language, and Culture in Britain's Long Eighteenth Century 
This volume has been prepared within the framework of the Collaborative Research Center SFB 1288 "Practices of Comparing. Changing and Ordering the World", Bielefeld University, Germany, funded by the German Research Foundation (DFG).

We acknowledge support for the publication costs by the Open Access Publication Fund of Bielefeld University.

SFB 1288

PRACTICES OF
Funded by

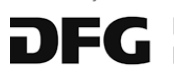

Deutsche

Forschungsgemeinschaft German Research Foundation

\section{Bibliographic information published by the Deutsche Nationalbibliothek}

The Deutsche Nationalbibliothek lists this publication in the Deutsche Nationalbibliografie; detailed bibliographic data are available in the Internet at http:// dnb.d-nb.de

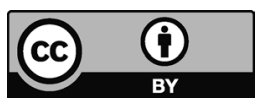

This work is licensed under the Creative Commons Attribution 4.0 (BY) license, which means that the text may be remixed, transformed and built upon and be copied and redistributed in any medium or format even commercially, provided credit is given to the author. For details go to http://creativecommons.org/licenses/by/4.o/

Creative Commons license terms for re-use do not apply to any content (such as graphs, figures, photos, excerpts, etc.) not original to the Open Access publication and further permission may be required from the rights holder. The obligation to research and clear permission lies solely with the party re-using the material.

\section{First published in 2022 by transcript Verlag, Bielefeld (c) Nadine Böhm-Schnitker, Marcus Hartner}

Cover layout: Maria Arndt, Bielefeld

Printed by Majuskel Medienproduktion $\mathrm{GmbH}$, Wetzlar

Print-ISBN 978-3-8376-5799-9

PDF-ISBN 978-3-8394-5799-3

https://doi.org/10.14361/9783839457993

ISSN of series: $2702-8968$

eISSN of series: $2702-8976$

Printed on permanent acid-free text paper. 